\title{
Formulation of Traditional Mask Powder Containing the Mixture of Coffea robusta, Angelica keiskei and Oryzae sativa, and its Activity as Tyrosinase Enzyme Inhibitor
}

\author{
Diah Lia Aulifa ${ }^{1, *}$, Annisa Sri Rahayu Berliana², Nur Asni Setiani², Arif Budiman ${ }^{3}$
}

Diah Lia Aulifa ${ }^{1, *}$, Annisa Sri Rahayu Berliana², Nur Asni Setiani², Arif Budiman ${ }^{3}$

'Department of Pharmaceutical Analysis and Medicinal Chemistry, Faculty of Pharmacy,

Universitas Padjadjaran, Jl. Raya Bandung

Sumedang Km. 21, INDONESIA.

${ }^{2}$ Sekolah Tinggi Farmasi Indonesia

(Indonesian School of Pharmacy), Jl

Soekarno Hatta no.354, Bandung,

INDONESIA.

${ }^{3}$ Department of Pharmaceutics and

Pharmaceutical Technology, Faculty of

Pharmacy, Universitas Padjadjaran, Jl. Raya

Bandung-Sumedang Km. 21, INDONESIA.

\section{Correspondence}

Diah Lia Aulifa

Department of Pharmaceutical Analysis and Medicinal Chemistry, Faculty of

Pharmacy, Universitas Padjadjaran, JI. Raya Bandung-Sumedang Km. 21, INDONESIA.

E-mail: diahliaaulifa@gmail.com

History

- Submission Date: 05-10-2021;

- Review completed: 23-10-2021;

- Accepted Date: 09-11-2021.

DOI : 10.5530/pj.2021.13.205

Article Available online

http://www.phcogj.com/v13/i6

Copyright

(C) 2021 Phcogj.Com. This is an openaccess article distributed under the terms of the Creative Commons Attribution 4.0 International license.

\begin{abstract}
Objective: Formulate a traditional mask powder with the mixture of Coffea robusta (CR) green bean, Angelica keiskei (AK) leaf and Oryzae sativa (OS) and evaluate its activity as an inhibitor of the enzyme tyrosinase. Methods: The traditional mask powder was formulated by mixing homogeneously CR bean, AK leaf and OS, which is sieved by $125-\mu \mathrm{m}$ sieve and sealed by foil aluminium. Subsequently, the traditional mask powder was evaluated including organoleptic, $\mathrm{pH}$ and microbial contamination test The total phenolic content of CR bean, AK leaf and OS was determined by Folin-Ciocalteu test, and the inhibitory activities of the tyrosinase enzyme was determined using L-Tyrosine as substrate. Results: The physical stability of the traditional mask powder containing CR bean, AK leaf and OS was stable after 7 days of storage. The total phenolic content of CR bean, AK leaf and OS were 9.51, 2.80 and 2.2 gGAE/100g, respectively. The CR bean, AK leaf and OS had tyrosinase enzyme inhibitor activity with $\mathrm{IC}_{50}$ value $321.52,930.10$ and $339.55 \mu \mathrm{g} / \mathrm{mL}$, respectively, while the $\mathrm{IC}_{50}$ of traditional mask powder was $127.60 \mu \mathrm{g} / \mathrm{mL}$, and the $\mathrm{IC}_{50} \mathrm{kojic}$ acid used as a positive control was $573.10 \mu \mathrm{g} / \mathrm{mL}$. Conclusion: This study demonstrated that the traditional mask powder made the mixture of the CR bean, AK leaf and OS has a potential as a skin lightening agent.
\end{abstract}

Key words: Angelica keiskei, Coffea robusta, Oryzae sativa, Traditional mask powder, Tyrosinase enzyme inhibitor.

\section{INTRODUCTION}

Skin aging and loss of tensile strength can cause wrinkles, roughness, and dryness. ${ }^{1-2}$ Furthermore, hyperpigmentation occurs due to the overproduction of melanin $^{3}$, and the accumulation and overproduction of melanin can lead to a serious aesthetic problem due to age spots or melasma. ${ }^{4-5}$ The enzyme tyrosinase is the key factor in the synthesis of melanin. ${ }^{3}$ Therefore, the inhibition of the activities of the tyrosinase enzyme would be an important step in preventing hyperpigmentation disorder. ${ }^{4-5}$ The use of natural sources as an inhibitor of the enzyme tyrosinase can be used as an alternative material due to the few harmful side effects.

Coffea robusta $\mathrm{L}$. (CR) is a natural source used in the inhibition of the tyrosinase enzyme. Caffeine and chlorogenic acid contained in CR Bean is a possible source as an antioxidant, due to its synergistic antioxidant, promotes tyrosinase inhibitory activity. ${ }^{7-8}$ The previous study showed that tyrosinase enzyme inhibitor activity of CR bean extract was observed similar to that of kojic acid used as a positive control. ${ }^{9}$

Angelica keiskei (AK) recognized as a medicinally important herb in Asia is also a plant that has a potential source as an antioxidant and tyrosinase enzyme inhibitor. ${ }^{6,10}$ Chalcones, which has two aromatic rings with an unsaturated chain, is one of the popular groups of compounds in AK that can prevent overproduction of melanin by tyrosinase enzyme inhibition. ${ }^{11}$ The previous studies reported that the isoprenoid-substituted moiety content in
AK leaf extract increased the flavonoid's ability to inhibit melanin biosynthesis. ${ }^{12}$ The xanthoangelol and 4-hydroxyderricin from $\mathrm{AK}$ extract can also inhibit tyrosinase enzyme with $\mathrm{IC}_{50}$ values of $15.87 \pm$ $1.21 \mu \mathrm{M}$ and $60.14 \pm 2.29 \mu \mathrm{M}$, respectively. ${ }^{13}$

Oryzae sativa (OS) has many bioactive functions, including immunomodulating agents, angiotensinI-converting enzyme (ACE) inhibitors, antibiotics, antioxidants, and opioids. ${ }^{14}$ In addition, the protein content in OS showed strong inhibitory activities against ACE, $\alpha$-amylase, and $\beta$-glucosidase. The previous study reported that peptide CT-2 (Leu-Gln-Pro-Ser-His-Tyr) isolated from rice bran efficiently inhibit melanogenesis in mouse, indicating that rice bran is a potential source as an agent for melanin-related skin disorder treatment. ${ }^{15}$

Despite the inhibitory activity of the tyrosinase enzyme of each material, the activity of the mixture was not examined. In this study, the traditional mask powder from the mixture of CR bean, AK leaf and OS was formulated, and evaluated its activity as an inhibitor of tyrosinase enzyme. In addition, the effect of CR bean, AK leaf and OS, alone, on tyrosinase enzyme activity was examined, and that the determined phenolic content was assumed to have a potential as tyrosinase enzyme inhibitory agent.

\section{MATERIALS AND METHODS}

\section{Plant material}

The AK leaf was collected from Lombok, West Nusa Tenggara, while CR green bean and OS were collected from Arjasari, Bandung, West Java,

Cite this article: Aulifa DL, Berliana ASR, Setiani NA, Budiman A. Formulation of Traditional Mask Powder Containing the Mixture of Coffea robusta, Angelica keiskei and Oryzae sativa, and its Activity as Tyrosinase Enzyme Inhibitor. Pharmacogn J. 2021;13(6)Suppl: 1594-1597. 
Indonesia. All materials were approved by the School of Life Sciences and Technology, Bandung Institute of Technology (ITB) No. 401/ I1.CO2.2/PL/2019 and No. 700/I1.CO2.2/PL/2019.

\section{Chemicals}

The tyrosinase enzyme, L-Tyrosine, Gallic acid and Quercetin were purchased from Sigma Aldrich, while kojic acid dipalmitate was purchased from Thornhill Advanced Research Inc. All other chemicals were of pharmaceutical and technical grades.

\section{Phytochemical screening}

Phytochemical screening was conducted to observe the presence of secondary metabolites in CR bean, AK leaf and OS, including flavonoids, alkaloids, quinones and phenols. ${ }^{17-18}$

\section{Determination of total phenolic content}

The total phenol content of all materials was determined using the Folin-Ciocalteu test. A total of $0.5 \mathrm{~mL}$ of each sample was dissolved in methanol (CR bean was $1000 \mathrm{ppm}$, AK leaf was $700 \mathrm{ppm}$ and OS was $4000 \mathrm{ppm}$ ) and mixed with $5 \mathrm{~mL}$ Folin-Ciocalteu reagent diluted with distilled water $(1: 10)$ and $4 \mathrm{~mL} \mathrm{Na}_{2} \mathrm{CO}_{3}(1 \mathrm{M})$. The mixture was incubated for 15 minutes and then determined spectrophotometrically at a wavelength of $765 \mathrm{~nm}$. The total phenol content was calculated in gallic acid equivalent (GAE), which was used as a general reference compound. ${ }^{19-20}$

\section{Tyrosinase Inhibitory Activity}

The sample was dissolved in phosphate buffer consisting of $50 \mathrm{mM}, \mathrm{pH}$ 6.8 , and $1 \%$ dimethyl sulfoxide to achieve the concentrations of 500 $\mu \mathrm{g} / \mathrm{mL} .70 \mu \mathrm{L}$ of the sample solution, which was added to $30 \mu \mathrm{L}$ of the tyrosinase enzyme (Sigma, 333 units $/ \mathrm{mL}$ in phosphate buffer) placed in the microwell plates. Furthermore, the plates were incubated for $5 \mathrm{~min}$ at room temperature, then approximately $110 \mu \mathrm{L}$ of the substrate in 1 $\mathrm{mM}$ L-tyrosine was added and incubated at room temperature for 30 min. The sample solution was measured using a microwell plate reader at a wavelength of $492 \mathrm{~nm}$ to determine the $50 \%$ inhibitory $\left(\mathrm{IC}_{50}\right)$ concentration value. The percentage of tyrosinase enzyme activity inhibition was determined as follows:

inhibition $(\%)=[(\mathrm{A}-\mathrm{B}) / \mathrm{A}] \times 100$,

A is the absorbance of kojic acid used as a reference at $492 \mathrm{~nm}$, and B is the absorbance of each sample at $492 \mathrm{~nm} .^{5}$

\section{Formulation of traditional mask powder}

The traditional mask powder was formulated by preparing the physical mixture from all materials. The CR bean, AK leaf and OS with weight ratio of 1:1:2 were ground by mortar and pestle, and sieved using a $125-\mu \mathrm{m}$ sieve. All materials were mixed to obtain a physical mixture and sealed using foil aluminium. Its physical stability was evaluated including organoleptic, $\mathrm{pH}$ and microbial contamination test after 7 day-storage.

\section{RESULT AND DISCUSSION}

Phytochemical screening result of CR bean, AK leaf and OS are shown on table 1.

The phenols were observed in all raw materials of traditional mask powder, indicating that $\mathrm{CR}$ bean, AK leaf and OS was predicted as a potential for tyrosinase enzyme inhibitory agent. To confirm the present of phenols in the raw materials, the total phenolic content of each material was determined using the Folin-Ciocalteu test. The result showed that the total phenolic content of CR bean, AK leaf and OS in terms of gallic acid equivalent were 9.51, 2.80 and $2.2 \mathrm{gGAE} / 100 \mathrm{~g}$, respectively.
The organoleptic characteristic of traditional mask powder from the mixture of CR bean, AK leaf and OS, did not change significantly after 7 days of storage. In addition, the $\mathrm{pH}$ of traditional mask powder from the mixture CR bean, AK leaf and OS after dispersed into water is shown in the figure 1 .

The result showed that the $\mathrm{pH}$ from the mixture of CR bean, AK leaf and OS were similar after 7 days of storage and remained within the acceptable $\mathrm{pH}$ for mask powder, which is between $4.5-6.5$, according to Indonesia National Standards (SNI). ${ }^{21}$ The value of significance was lower than 0.05 , indicating that the difference of $\mathrm{pH}$ after 7 days of storage was not significant.

The result of microbial contamination test of traditional mask powder from the mixture of CR bean, AK leaf and OS is shown in table 3 .

The result showed that the number of bacteria of traditional mask powder from the mixture of CR bean, AK leaf and OS sativa remained within the acceptable number of bacteria, according to the Indonesia National Standards (SNI). The specify limits on total yeast and mold counts was $1 \times 10^{4} \mathrm{CFU} /$ gram, while for bacteria was $1 \times 10^{6} \mathrm{CFU} / \mathrm{gram} .{ }^{21}$ These findings indicated that traditional mask powder from the mixture of CR bean, AK leaf and OS was safe to be used as a topical preparation, especially as a skin lightening agent.

\section{Tyrosinase enzyme inhibitory activity}

The tyrosinase enzyme inhibitory activity from CR bean, AK leaf, OS and traditional mask powder were determined by measuring the amount of dopachrome from L-tyrosine, as shown in Table-3.

The result showed that the $\mathrm{IC}_{50}$ values of CR bean and OS were lower than kojic acid, indicating that the activity in tyrosinase enzyme inhibition was stronger than kojic acid. The high amounts of total phenolic compounds contained in coffee and its synergistic antioxidant lead to a good tyrosinase enzyme inhibition. ${ }^{22-23}$ The previous study reported that feruloyl sucrose ester isolated from OS can inhibit tyrosinase enzyme. ${ }^{24}$ In addition, AK leaf was higher than kojic acid, indicating that tyrosinase enzyme inhibitory activity in the AK leaf was weaker than kojic acid. This data was in line with the previous study, which reported that chalcones content in AK leaf showed an inhibitory activity of the enzyme tyrosinase. ${ }^{12}$

\section{Table 1: Phytochemical screening result of CR bean, AK leaf and OS.}

\begin{tabular}{lcccc}
\hline Plant species & Flavonoids & Alkaloids, & Quinones & Phenols \\
CR bean & + & + & + & + \\
AK leaf & + & + & + & + \\
OS & - & - & + & +
\end{tabular}

Table 2: The result of microbial contamination test of traditional mask powder from the mixture of CR bean, AK leaf and OS.

\begin{tabular}{cc}
\hline Days & The number of bacteria (CFU/gram) \\
\hline 0 & $7.65 \times 10^{2}$ \\
3 & $3.10 \times 10^{1}$ \\
5 & $3.50 \times 10^{1}$ \\
7 & $5.71 \times 10^{1}$ \\
\hline
\end{tabular}

Table 3: The tyrosinase enzyme inhibitory activity of traditional mask powder from the mixture of CR bean, AK leaf and OS.

\begin{tabular}{|cc|}
\hline Sample & $\mathrm{IC}_{50}(\mu \mathrm{g} / \mathrm{mL})$ \\
\hline CR bean & 321.52 \\
AK leaf & 930.10 \\
OS & 339.55 \\
Kojic acid & 573.10 \\
Traditional mask powder & 127.60 \\
\hline
\end{tabular}




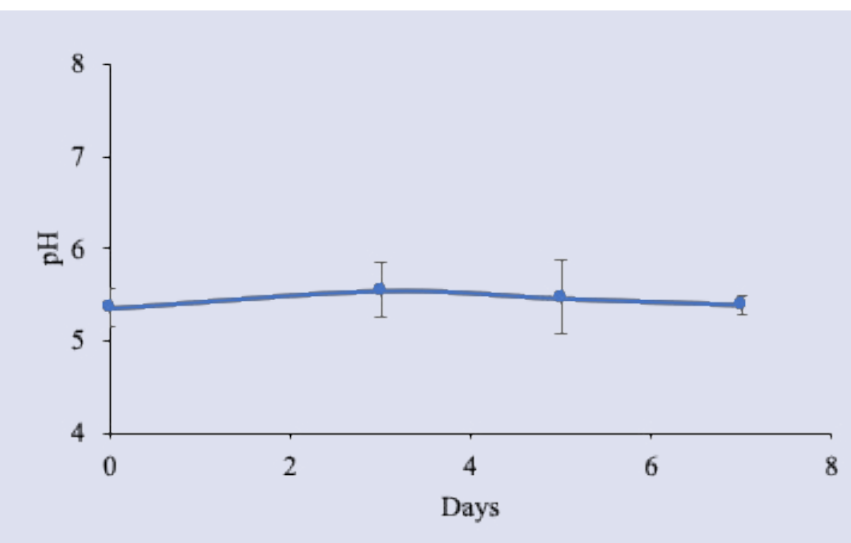

Figure 1: $\mathrm{pH}$ of traditional mask powder from the mixture $\mathrm{CR}$ bean, AK leaf and OS after dispersed into water.

Interestingly, the $\mathrm{IC}_{50}$ values of the traditional mask powder was higher than other sample (CR bean, AK leaf, OS and kojic acid), indicating that its enzyme tyrosinase inhibitory activity was the strongest. It was speculated that the combination of CR bean, AK leaf, OS showed strong synergistic activity in tyrosinase enzyme inhibitory. However, the mechanism of synergistic activity needs further investigated, especially the relationship between the compound contained in traditional mask powder with tyrosinase enzyme inhibitory activity. In order to fully understand its potentials as a skin lightening agent. This study was the initial research regarding the synergistic activity of CR bean, AK leaf, OS on tyrosinase enzyme inhibitory.

\section{CONCLUSION}

In this study, tyrosinase enzyme inhibitory of the traditional mask powder from the mixture of CR bean, AK leaf, OS was investigated. The mixture of CR bean, AK leaf, OS was successfully formulated into the traditional mask powder, the physical stability was acceptable according to the Indonesia National Standards (SNI). An in vitro study showed that the $\mathrm{IC}_{50}$ of traditional mask powder was lower than every of its component, indicating that synergistic activity from the combination of CR bean, AK leaf, OS in tyrosinase enzyme inhibitory was observed. However, further research on its synergistic activity in relation to the inhibitory activities of the enzyme tyrosinase is needed to fully understand its potentials as a skin lightening agent. This study provides the first research results on the synergistic activity of the plant material mixture on inhibitors of the enzyme tyrosinase, which was safe as a topical preparation, especially as a skin lightening agent.

\section{REFERENCES}

1. Quan T, Qin Z, Xia W, Shao Y, Voorhees JJ, Fisher GJ. Matrix-degrading Metalloproteinases in Photoaging. J Investig Dermatol Symp Proc. 2009; 14(1):20-24.

2. Costin GE, Hearing VJ. Human Skin Pigmentation: Melanocytes Modulate Skin Color in Response to Stress. FASEB J. 2007;21(4):976994.

3. Limtrakul P, Yodkeeree S, Thippraphan P, Punfa W, Srisomboon J. Anti-aging and Tyrosinase Inhibition Effects of Cassia fistula Flower Butanolic Extract. BMC Complement Altern Med. 2016;16(1):1-9.

4. Budiman A, Khaira N, Aulifa DL. Peel-off Gel Formulation From Black Mulberries (Morus Nigra L.) Leaves Extract as a Tyrosinase Inhibitor. Int J Drug Deliv Technol. 2019;9: 525-529.

5. Adhikari A, Devkota HP, Takano A, Masuda K, Nakane T, Basnet $P$, Skalko-Basnet N. Screening of Nepalese Crude Drugs Traditionally Used to Treat Hyperpigmentation: in vitro tyrosinase inhibition. Int $J$ Cosmet Sci. 2008;30(5):353-360.
6. Willis I, Kligman A, Epstein J. Effects of Long Ultraviolet Rays on Human Skin: Photoprotective or Photoaugmentative?. J Invest Dermatol. 1972;59(6):416-420.

7. Kiattisin K, Nantarat T, Leelapornpisid P. Evaluation of Antioxidant and Anti-Tyrosinase Activities as well as Stability of Green and Roasted Coffee Bean Extracts from Coffea arabica and Coffea canephora Grown in Thailand. J Pharmacogn Phytotherapy. 2016;8(10):182-192.

8. Jeszka-Skowron M, Sentkowska A, Pyrzyńska K, De Peña MP. Chlorogenic acids, Caffeine Content and Antioxidant Properties of Green Coffee Extracts: Influence of Green Coffee Bean Preparation. Eur Food Res Technol. 2016;242(8):1403-1409.

9. Aulifa DL, Noerfitri RY, Tristiyanti D, Budiman A. Formulation of Serum Gel Containing Angelica keiskei Leaf Extract as an Antioxidant and Tyrosinase Enzyme Inhibitor. Int J Appl Pharm. 2020;12(3):108-111.

10. Li L, Aldini G, Carini M, Chen CY, Chun HK, Cho SM, Park KM, Correa $\mathrm{CR}$, Russell RM, Blumberg JB, Yeum KJ. Characterisation, Extraction Efficiency, Stability and Antioxidant Activity of Phytonutrients in Angelica keiskei. Food Chem. 2009;115(1):227-232.

11. Nerya O, Musa R, Khatib S, Tamir S, Vaya J. Chalcones as Potent Tyrosinase Inhibitors: The Effect of Hydroxyl Positions and Numbers. Phytochem. 2004;65(10):1389-1395.

12. Arung ET, Furuta S, Sugamoto K, Shimizu K, Ishikawa H, Matsushita $\mathrm{Yl}$ et al. The Inhibitory Effects of Representative Chalcones Contained in Angelica keiskei on Melanin Biosynthesis in B16 Melanoma Cells. Nat Prod Commun. 2012;7(8):1007-1010

13. Lee JH, Mei HC, Kuo I, Lee TH, Chen YH, Lee CK. Characterizing Tyrosinase Modulators from the Roots of Angelica keiskei Using Tyrosinase Inhibition Assay and UPLC-MS/MS as the Combinatorial Novel Approach. Molecules. 2019;24(18):3297.

14. Kitts DD, Weiler K. Bioactive Proteins and Peptides from Food Sources. Applications of Bioprocesses Used in Isolation and Recovery. Curr Pharm Des. 2003;9(16):1309-1323.

15. Uraipong C, Zhao J. Rice Bran Protein Hydrolysates Exhibit Strong In Vitro A-Amylase, B-Glucosidase and ACE-Inhibition Activities. J Sci Food Agric. 2016;96(4):1101-1010.

16. Ochiai A, Tanaka S, Tanaka T, Taniguchi M. Rice Bran Protein as A Potent Source of Antimelanogenic Peptides with Tyrosinase Inhibitory Activity. J Nat Prod. 2016;79(10):2545-2551.

17. Budiman A, Rusnawan DW, Yuliana A. Antibacterial Activity of Piper Betle L. Extract in Cream Dosage Forms Against Staphylococcus aureus and Propionibacterium acne. J Pharm Sci Res. 2018;10(3):493-496.

18. Budiman A, Praditasari A, Rahayu D, Aulifa DL. Formulation of Antioxidant Gel from Black Mulberry Fruit Extract (Morus nigra L.). J Pharm Bioallied Sci. 2019;11(3):216.

19. Fitriansyah SN, Aulifa DL, Febriani Y, Sapitri E. Correlation of Total Phenolic, Flavonoid and Carotenoid Content of Phyllanthus emblica Extract from Bandung with DPPH Scavenging Activities. Pharmacogn J. 2018;10(3):447-52.

20. Pourmorad SJ, Hosseinimehr, Shahabimajd N. Antioxidant Activity, Phenol and Flavonoid Contents of Some Selected Iranian Medical Plants. Afr J Biotechnol. 2006:5(11):1142-45.

21. Health Department of Indonesia. General Standard Parameters of Medicinal Plant Extracts. Ministry of Health of the Republic of Indonesia; 2000.

22. Chang TS. Review an Update Review of Tyrosinase Inhibitors. Int J Mol Sci. 2009;10(6):2440-2475

23. Kiattisin K, Nantarat T, Leelapornpisid P. Evaluation of Antioxidant and Anti-Tyrosinase Activities as well as Stability of Green and Roasted Coffee Bean Extracts from Coffea arabica and Coffea canephora Grown in Thailand. J Pharmacogn Phytotherapy. 2016;8(10):182-192.

24. Cho JG, Cha BJ, Seo WD, Jeong RH, Shrestha S, Kim JY, Kang HC Baek NI. Feruloyl Sucrose Esters from Oryza sativa Roots and Their Tyrosinase Inhibition Activity. Chem Nat Compd. 2015;51(6):1094-8. 


\section{GRAPHICAL ABSTRACT}
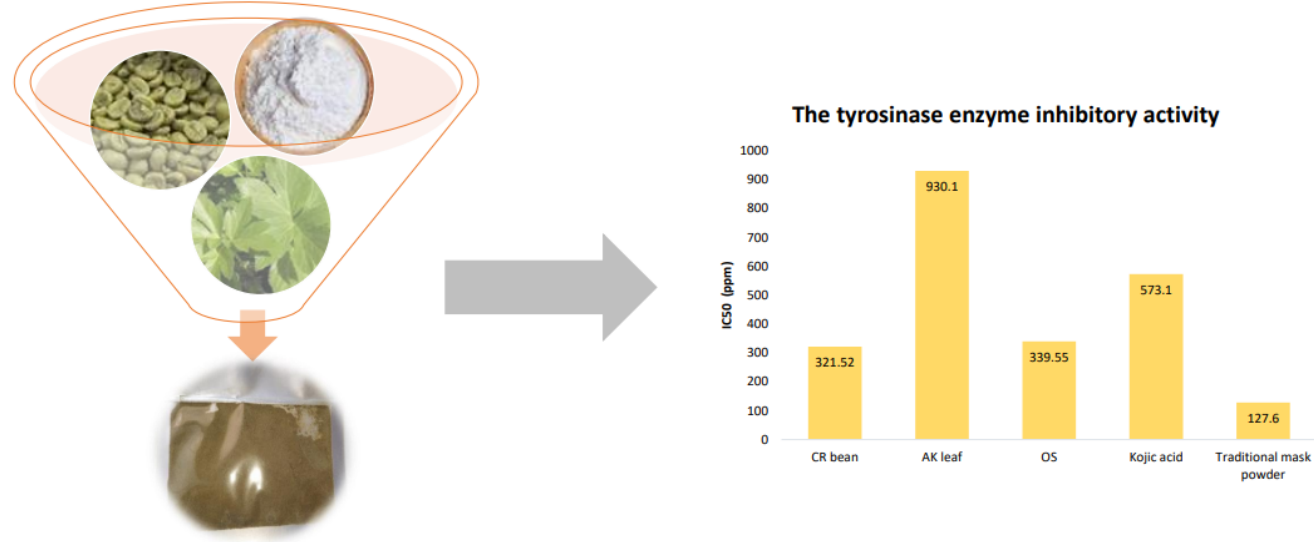

Traditional mask powder

The tyrosinase enzyme inhibitory activity of traditional mask powder from the mixture of Coffea robusta (CR) green bean, Angelica keiskei (AK) leaf and Oryzae sativa (OS) compared with kojic acid as reference

\section{ABOUT AUTHORS}
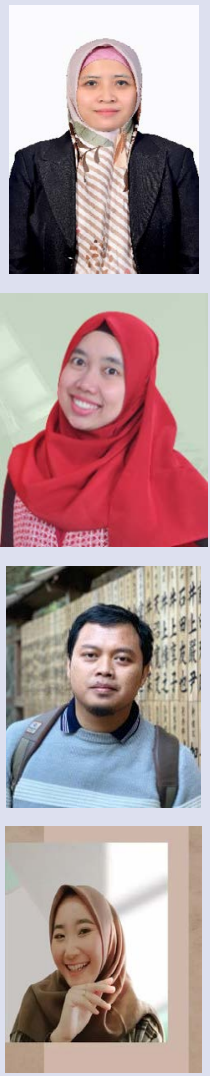

Diah Lia Aulifa is a lecturer in Department of Pharmaceuticals Analysis and Medicinal Chemistry, Faculty of Pharmacy Universitas Padjadjaran. Develop work in pharmacognosy molecular and phytochemistry.

Nur Asni Setiani is a lecturer in Sekolah Tinggi Farmasi Indonesia (Indonesian School of Pharmacy), Bandung-Indonesia, Department of Pharmacology. Current research interest are pharmacology, biotechnology, and microbiology.

Arif Budiman is a lecturer in Department of Pharmaceutics and Pharmaceutical Technology, Faculty of Pharmacy Universitas Padjadjaran. Develop work in physical pharmacy and pharmaceutical dosage forms development.

Annisa Sri Rahayu Berliana is an undergraduate student of the Pharmacy Course, Sekolah Tinggi Farmasi Indonesia (Indonesian School of Pharmacy), Bandung-Indonesia.

Cite this article: AAulifa DL, Berliana ASR, Setiani NA, Budiman A. Formulation of Traditional Mask Powder Containing the Mixture of Coffea robusta, Angelica keiskei and Oryzae sativa, and its Activity as Tyrosinase Enzyme Inhibitor. Pharmacogn J. 2021;13(6) Suppl: 1594-1597. 